\title{
Mechanical Characterization of Jute-Carbon-E Glass Sandwich Panel Hybrid Composite
}

\author{
Naveen Ankegowda, Nityaanada B S, K B Vinay, G V Naveen Prakash
}

\begin{abstract}
A sandwich- honeycomb structured panel hybrid composite has been prepared using jute -carbon - E glass fibersepoxy resign and polyurethane foams. A sandwich is a special class of composite materials that is fabricated by attaching two thin but stiff skins to a lightweight but thick core. The jute material has been used as core which is normally natural fiber which is biodegradable good insulating properties, high tensile strength, low extensibility, and ensures better breathability. Carbon fiber and $E$ glass fiber used as faces sheets. In this paper mechanical characterization of Jute-Carbon-E Glass Sandwich Panel Hybrid Composite has been carried out and in particular compression, impact, flexural and hardness test.
\end{abstract}

Index Terms: Jute fiber, Carbon fiber, $E$ glass fiber sandwich honey comb structured, Compression, Impact, Flexural and Hardness Test

\section{INTRODUCTION}

Present-day composites results from research and innovation from past few decades have advanced from glass fiber for automobile bodies to particulate composites for aerospace and a range other applications. Composites that forms assorted structures which meet the requirements of specific design and function, imbued with desired properties which limit the scope for classification. However, this lapse is made up for, by the fact new types of composites are being innovated all the time, each with their own specific purpose like "the filled, flake, particulates and laminar composites". A sandwich-structured composite is a exceptional class of materials that is made-up off core and two thin facing sheets which is less in weight attached core. The core material is should be of low strength, but at its higher thickness provides high bending stiffness with low density. The core is bonded to thin sheets with an adhesive or with metal components by brazing it together. The structure of Honeycomb permits minimal weight since it reduces the amount of material used. In order to stabilize thermal and insulating properties the honeycomb cell walls, stiff foam has been packed. Thus in the sandwich honeycomb will act as core. On either side of the honeycomb core, facing sheets are laminated using the adhesives and the extensively used adhesives is epoxy resin. Fig. 1 shows the honey comb sandwich structure

Revised Manuscript Received on December 5, 2019.

Correspondence Author

Naveen Ankegowda*, Dept. of Mechanical Engineering, VVCE, India. Email: naveen@vvce.ac.in

Nithyananda B. S, Dept. of Mechanical Engineering, VVCE, India,

Dr. G.V Naveen Prakash, Dept. of Mechanical Engineering,VVCE, India.

Dr. K B Vinay, Dept. of Mechanical Engineering, VVCE, India

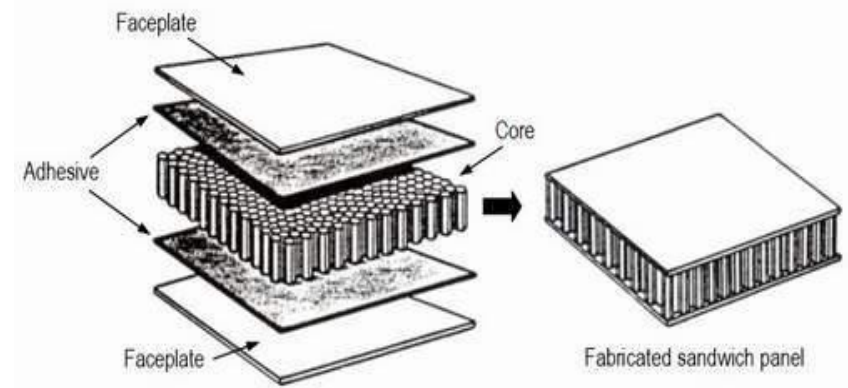

Fig. 1 Honey comb sandwich structure

\section{METHODOLOGY}

\section{A. MATERIAL SELECTION}

Based on the literature, the materials used are finalized. Jute fiber has been used to fabricate the honeycomb structure as core. Shell of honeycomb has been filled with polyurethane foam to bring the stability of shell. The carbon and E glass fiber have used as facing sheets. Epoxy resin has been used as adhesive to laminate the facing sheets. The jute fibers have been extracted from the stem of the plant, allowed it retting in water then beating, stripping and drying. Jute has been selected, since it is biodegradable, insulating property against thermal and acoustic energies. And also possess good tensile strength, modulus to weight ratio and ensures breathability. Carbon fiber is strongest than steel and lighter in weight. E glass fiber is electrical grade stronger than " $\mathrm{A}$ " grade alkali which possesses good tensile and compressive strength. Table 1 shows properties of E grade glass fiber (“E”), jute (J), carbon (C).

Table 1 Properties of Jute, Carbon, E-glass fiber

\begin{tabular}{cccc}
\hline Property & E & J & C \\
\hline $\begin{array}{c}\text { Specific Gravity } \\
\text { Tensile Strength } \\
\left(\mathrm{MN} / \mathrm{m}^{2}\right)\end{array}$ & 2.5 & 1.3 & 1.95 \\
$\begin{array}{c}\text { Young's Modulus } \\
\left(\mathrm{GN} / \mathrm{m}^{2}\right)\end{array}$ & 72 & 55.5 & 227.5 \\
$\begin{array}{c}\text { Specific Strength } \\
\left(\mathrm{MN} / \mathrm{m}^{2}\right)\end{array}$ & 1360 & 340 & 2220 \\
$\begin{array}{c}\text { Specific Modulus } \\
\left(\mathrm{GN} / \mathrm{m}^{2}\right)\end{array}$ & 28.8 & 42.7 & 18.3 \\
\hline
\end{tabular}

Epoxies resin has mechanical properties and resistance to environmental degradation. Polyurethane Foams has good acoustic absorption.it can be readily cut into any shapes. 


\section{B. FABRICATION}

The jute-carbon- E Glass fiber honeycomb sandwich panels have been fabricated through vacuum bag molding technique, which uses the vacuum to eliminate the entrapped air and excess resin. The adhesive used is epoxy resin LY 556 mixed with hardener HY 951. The resin and hardener is mixed in the weight ratio of 10:1. To maintain optimum strength of the matrix, the ideal resin to fiber ratio is found to be 35:65. Hexagonally machined split molding tool which is made of mild steel and chromium plated are used. After ensuring the surface is cleaned to free from foreign particles, a releasing agent is applied. A coat of resin mixture is applied and jute fiber is impregnated. The resin impregnated fiber is first kept in oven for 2 hours at $100{ }^{\circ} \mathrm{C}$, 2hours at $120{ }^{\circ} \mathrm{C}$ and finally at $140{ }^{\circ} \mathrm{C}$ for about 6 hours for curing the core. Polyurethane Foams has been filled as filler to increase the impact strength. This core is bonded with facing sheets both on top and bottom. The thickness of facing sheets is $2 \mathrm{~mm}$. Facing sheets are made of both Carbon and E-glass fiber is of $0.2 \mathrm{~mm}$ in thickness, arranged alternatively to thickness of $2 \mathrm{~mm}$. The honeycomb sandwich panel has been fabricated to a size of $300 * 300 * 20$. The dimensions are in millimeter. The jute fiber core has been $16 \mathrm{~mm}$ and facing sheets up to $2 \mathrm{~mm}$ on either side.

\section{RESULTS AND DISCUSSION}

During fabrication three variants of the sandwich panel were fabricated based on the shell size viz. $6 \mathrm{~mm}, 8 \mathrm{~mm}$ and $10 \mathrm{~mm}$. all the test were carried out on the three variants of specimens. The tests are carried out according to ASTM standards.

\section{A. COMPRESSION test}

The compression test was carried out on FIE Make Universal Testing Machine, UTE-40, Width= $49 \mathrm{~mm}$, Thickness= $20 \mathrm{~mm}$, Final area $=790 \mathrm{~mm}^{2}$. The test was carried by varying the load. A load vs displacement graph was plotted for each specimen.

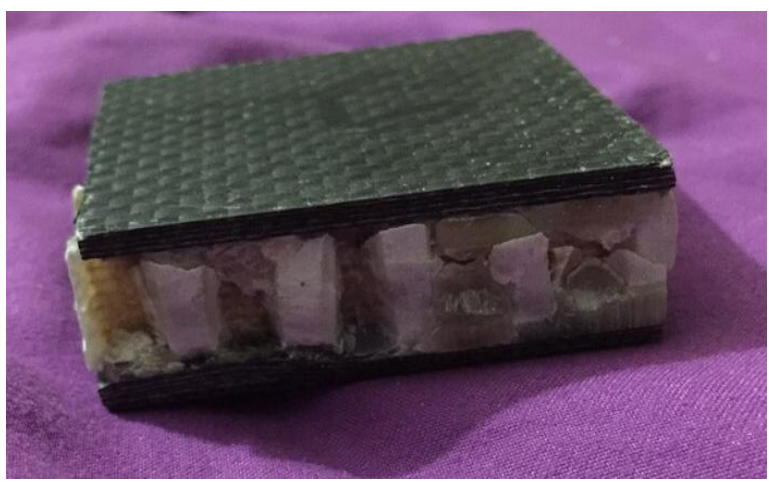

Fig. 2 Broken specimen after compression test

Fig. 3,Fig. 4 and Fig. 5 are the graph plotted between load versus displacement of the specimen of shell size $6 \mathrm{~mm}, 8 \mathrm{~mm}$ and $10 \mathrm{~mm}$ respectively. From the Fig. 3 it is observed that maximum force is $89.9 \mathrm{kN}$. The displacement observed at the Maximum force value was found to be $2.9 \mathrm{~mm}$. The compression strength obtained was 84.117 MPa. And from Fig. 4 of honeycomb of shell size $8 \mathrm{~mm}$, it is perceived that at maximum force is $195.78 \mathrm{kN}$, The displacement observed is $9.3 \mathrm{~mm}$. The compression strength obtained was 193.02

MPa. For the shell size $10 \mathrm{~mm}$, from fig.5, displacement is minimum at maximum force of $37.86 \mathrm{kN}$ and compression strength it is found to be minimum $38.261 \mathrm{Mpa}$. Therefore is concluded.

That the shell size of $8 \mathrm{~mm}$ performed better compared to $6 \mathrm{~mm}$ and $10 \mathrm{~mm}$. The best result has been for $8 \mathrm{~mm}$ and its compressive strength has been 193.019 Mpa and the next best result is for shell size $6 \mathrm{~mm}$ found at $84.117 \mathrm{Mpa}$.

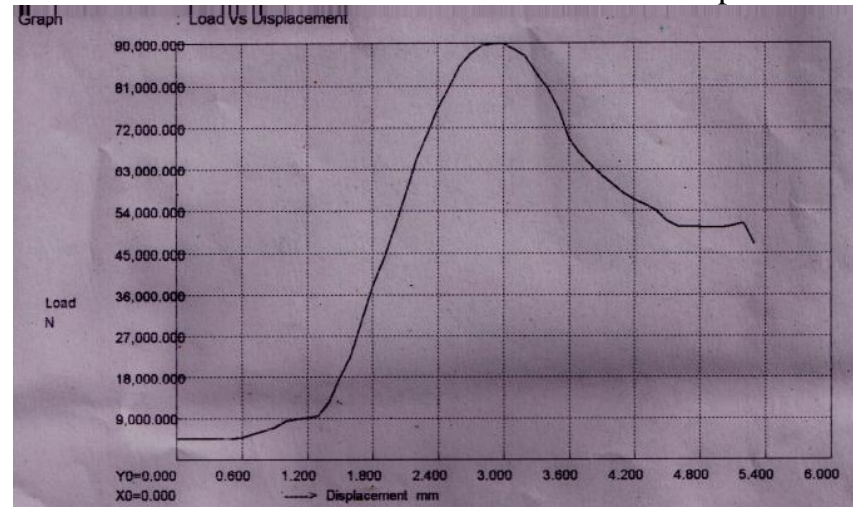

Fig. 3 Load vs displacement for shell diameter $6 \mathrm{~mm}$

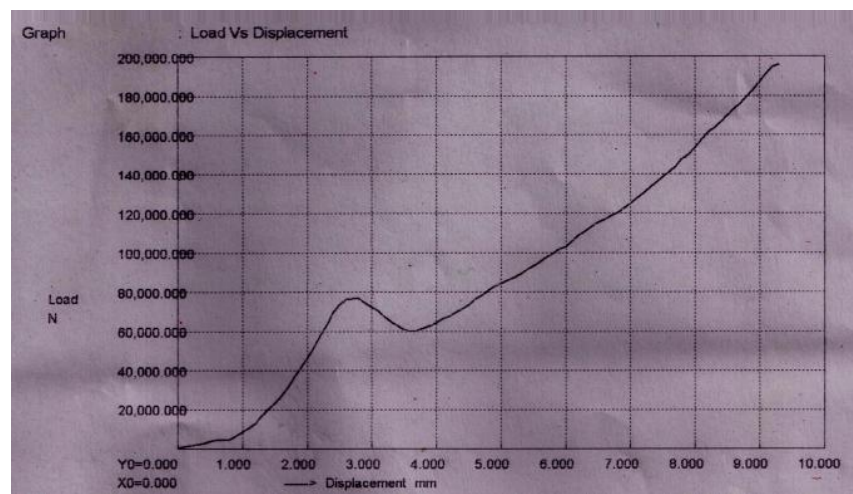

Fig. 4 Load vs displacement for shell diameter $8 \mathrm{~mm}$

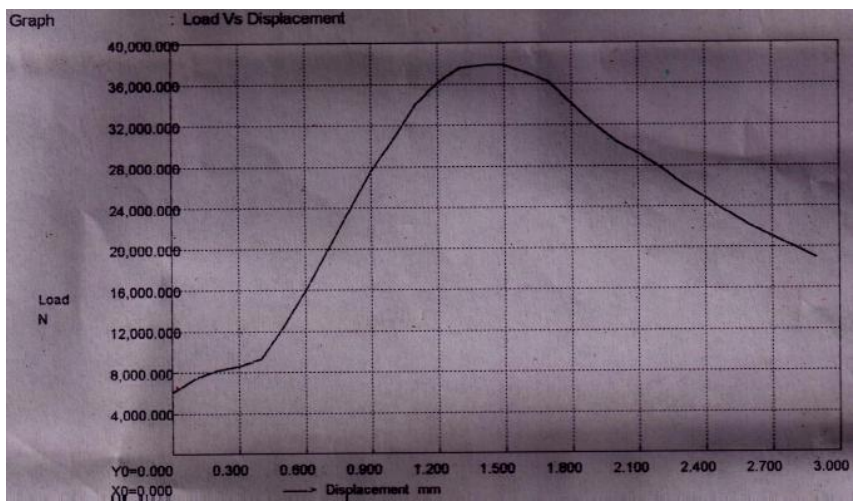

Fig. 5 Load vs displacement for shell diameter $10 \mathrm{~mm}$

Table 2. Results of compression strength

\begin{tabular}{|c|c|c|c|c|c|}
\hline SI no & $\begin{array}{c}\text { Shell } \\
\text { Diamete } \\
\mathbf{r}\end{array}$ & $\begin{array}{c}\text { Max. } \\
\text { Force }\end{array}$ & $\begin{array}{c}\text { Displacemen } \\
\text { t At Max. } \\
\text { Force }\end{array}$ & $\begin{array}{c}\text { Final C/S } \\
\text { Area (So) }\end{array}$ & $\begin{array}{c}\text { Compressi } \\
\text { on } \\
\text { Strength }\end{array}$ \\
\hline 1 & 6 & 89.9 & 2.9 & 1068.745 & 84.117 \\
\hline 2 & 8 & 195.78 & 9.3 & - & 193.019 \\
\hline 3 & 10 & 37.86 & 1.4 & 989.528 & 38.261 \\
\hline
\end{tabular}




\section{B. Bending test}

Bending or Flexural strength is also called as Modulus of Rupture The flexural strength of honeycomb sandwich structured material is defined as the maximum bending stress that can applied on the before it fails. Testing will be conducted by engaging a transverse bending test.

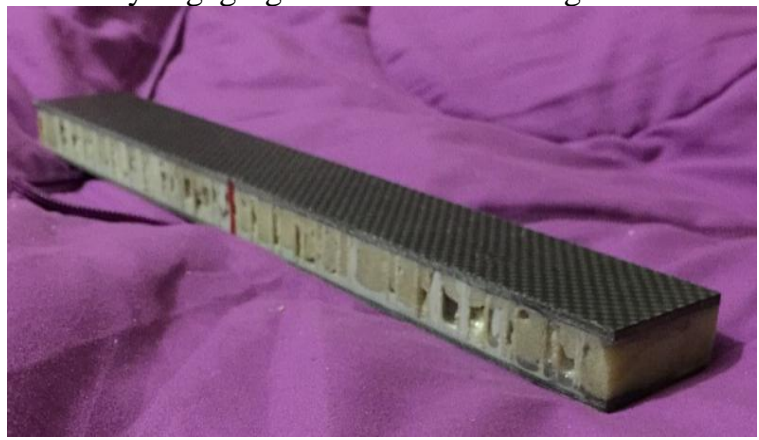

Fig. 6 Flexural Strength Specimen

Figure 6 shows one of the specimens prepared for flexural test. Table 3 gives the results of flexural strength conducted on all three variants of different shell diameter.

Table 3 Result of flexural strength

\begin{tabular}{|c|c|c|}
\hline Specimen & $\begin{array}{c}\text { Shell diameter } \\
(\mathrm{mm})\end{array}$ & $\begin{array}{c}\text { Flexural Strength } \\
(\mathrm{MPa})\end{array}$ \\
\hline 1 & 6 & 43.31 \\
\hline 2 & 8 & 103.71 \\
\hline 3 & 10 & 78.95 \\
\hline
\end{tabular}

From table 3 shows that specimen with $8 \mathrm{~mm}$ shell diameter has greater flexural strength i.e. $103.71 \mathrm{Mpa}$ when compared to $6 \mathrm{~mm}$ and $10 \mathrm{~mm}$ shell size of $43.31 \mathrm{Mpa}$ and $78.95 \mathrm{Mpa}$ respectively. It can sustain higher bending loads. The specimen having shell diameter of $6 \mathrm{~mm}$ has the least flexural strength.

\section{Impact test}

For impact test, charpy technique has been carried out. For a composite material test can be conducted with or without notch at its mid length which has been simply supported and swing load is applied. Upon impact the material breaks from which toughness or impact strength of the specimen can be calculated. The test was carried out at $28^{\circ} \mathrm{C}$. The results obtained are tabulated as shown below

Table 4 Results of Impact Strength

\begin{tabular}{|c|c|c|}
\hline PARTICULARS & $\begin{array}{c}\text { SHELL } \\
\text { DIAMETER } \\
(\mathrm{mm})\end{array}$ & $\begin{array}{c}\text { IMPACT } \\
\text { STRENGTH } \\
(\mathrm{J} / \mathrm{cm} 2)\end{array}$ \\
\hline SPECIMEN 1 & 6 & 17 \\
\hline SPECIMEN 2 & 8 & 26 \\
\hline SPECIMEN 3 & 10 & 20 \\
\hline
\end{tabular}

Charpy impact test was carried out, The result shows that the impact strength of the specimen with shell diameter $8 \mathrm{~mm}$ is the greatest. It can withstand higher impact strength.

\section{HARDNESS TEST}

The hardness testing method used to carry out this test was Shore hardness test. This test consist of two scales Shore A and Shore D. Shore A scale is used for 'softer' rubbers while the Shore D scale is used for 'harder' ones. In our test we have used the Shore D scale. The results obtained are tabulated in table 5 .
Table 5 Results of Hardness test

\begin{tabular}{|c|c|c|}
\hline PARTICULARS & $\begin{array}{c}\text { SHELL DIAMETER } \\
(\mathrm{mm})\end{array}$ & $\begin{array}{c}\text { HARDNESS } \\
\text { (SHORE D) }\end{array}$ \\
\hline SPECIMEN 1 & 6 & 56 \\
\hline SPECIMEN 2 & 8 & 72 \\
\hline SPECIMEN 3 & 10 & 62 \\
\hline
\end{tabular}

The result shows that the specimen 2 , with shell diameter of $8 \mathrm{~mm}$ has got the greatest hardness i.e. 72. Hardness of the specimen with shell diameter $6 \mathrm{~mm}$ is the least i.e. 56 .

A Figure 7 shows plot of graph between strength versus specimens.

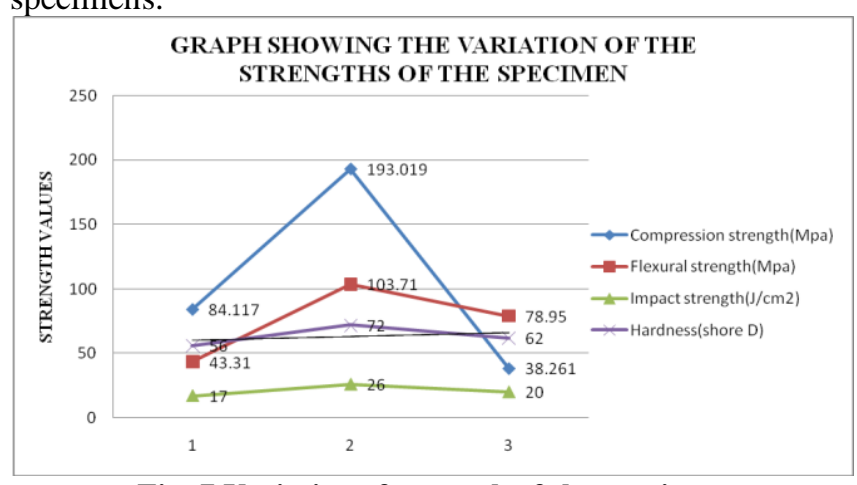

Fig. 7 Variation of strength of the specimen

The results obtained from the tests carried out shows that the jute core sandwich panel can withstand higher impact strength than that of a mild steel specimen. This is a clear indication that the jute core panel can be used in the bumpers of a car, thus, replacing the conventional materials. Also, the specimen with shell diameter of $8 \mathrm{~mm}$ has the optimal mechanical properties to be effectively used in various applications. The shell size should neither be large nor small. The results obtained prove that Jute core sandwich panel composites have a great potential to revolutionize the manufacturing market. The lower cost of the composite, higher weight to mass ratio and greater impact strength are an added advantage of this sandwich panel composite.

\section{CONCLUSION}

The Jute-Carbon-E glass sandwich panel fabricated has the potential to replace conventional materials used in the manufacturing processes. The results obtained shows appreciable impact, flexural and compression strengths. The high impact strength of the composite panel makes it suitable to be used in automobile industry. The objective of obtaining high impact strength was achieved. Jute can replace synthetic materials used as the core in sandwich panels, thus making the panels ecofriendly. The use of jute can also boom the Indian economy; India being the largest producer of jute. The higher water absorptivity of jute fibers can be overcome by using various methods for the enhancement of hydrophobic nature. The sandwich panel fabricated has many advantages over its counterparts making it one of the potential revolutionizer of the manufacturing industry. The results obtained depicts that the $8 \mathrm{~mm}$ panel has better results compared to the $6 \mathrm{~mm}$ and $10 \mathrm{~mm}$ panel. As the shell size decreases the stiffness of the panel increases which inturn decreases the strength of the panel. So, stiffness is inversely proportional to the strength of the panel.

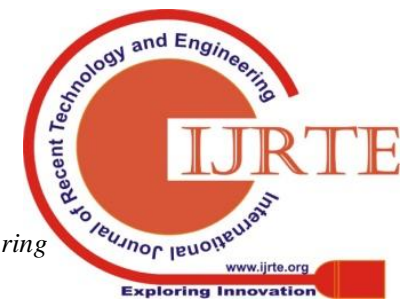




\section{REFERENCES}

1. Zenkert D. The handbook of sandwich construction. London: EMAS Publishing ; 1992

2. DIAB Sandwich Handbook",Diab Co.

3. Karssson KF, Astrcom.T."Manufacturing \& application of structural sandwich components", Composite Part A, Volume 28, issue 2, pp. 97-111, 1997

4. Weeks CA,Sun CT.Multi-core composite laminates.J Advancese Materials 1994:28-37

5. Wu CL, Sun CT. "Low velocity impact damage in composite sandwich beams", Composite structure, Volume 34, issue 1, pp21-27, 1996.

6. Mines RAW,Worrall CM,Gibson AG. "Low velocity perforation behavior of polymer composite sandwich panels".Int.J Impact Eng 1998:21(10):855-79

7. K.Kantha Rao, K. Jayathirtha Rao, A.G.Sarwade, B.Madhava Varma, "Bending Behaviour of Aluminium Honey Comb Sandwich Panels", International Journal of Engineering and Advanced Technology (IJEAT), ISSN: $2249-8958,2002$

8. Dipak G, Vamja1 , G. G. Tejani “Experimental test on sandwich panel composite material" , International Journal of Innovative Research in Science, Engineering and Technology, ISSN: 2319-8753, Vol.2,Issue 7, July 2013

9. Ahamed and Mahanwar, " The effect of fly ash as filler on the mechanical properties of HDPE" Journal of Minerals \& Materials Characterization \& Engineering, Vol. 9, No.3, pp.183-198, 2010.

10. Enrico Papa, Alberto Corigliano and Egidio Rizzi "Experimental investigation into the mechanical behavior of a composite sandwich", Journal of Mechanical Engineering,. Volume 12, Number 2, pp. 169-188, 2001

11. S K Acharya, P Mishra and S C Mishra, "Effect of environment on the mechanical properties of fly ash-jute polymer composite", Indian Journal of Engineering and material Science, volume 15 , pp.483-488,2008

12. Monteiro S.N.; Rodriquez R.J.S.; De Souza M.V., D'Almeida J.R.M., "Sugar Cane Bagasse Waste as Reinforcement in Low Cost Composites", Advanced Performance Materials, Volume 5, Issue 3, pp 183-191, 1998

13. A. N. Shah and S. C. Lakkad, Mechanical Properties of Jute-Reinforced Plastics. Fibre Science and Technology, Volume 15, Issue 1, July, Pages 41-46, 1981

14. D. Ray, B.K. Sarkara, A.K. Rana, and N.R. Bose "The mechanical properties of vinylester resin matrix composites reinforced with alkali-treated jute fibers", Composites Part A Applied Science and Manufacturing 32(1),pp.119-127, 2001

\section{AUTHORS PROFILE}

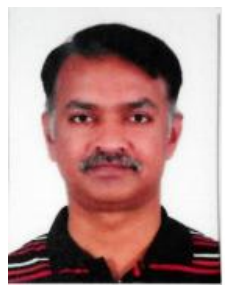

Mr. Naveen A (Naveen Ankegowda) is presently working as assistant professor at VVCE, Mysuru, India. He has obtained his bachelor's degree in Mechanical Engineering from KIT,Tiptur , Karnataka, India and Master Degree in Maintenance from SJCE, Mysuru, India. He has published more than 15 papers in journals and conferences. $\mathrm{He}$ is the member for MISTE professional body.

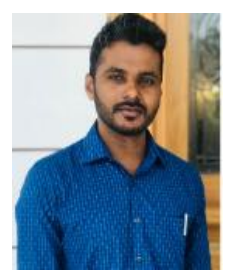

Mr. Nithyananda B S is Assistant Professor in the Department of Mechanical Engineering, VVCE, Mysuru. $\mathrm{He}$ did his BE in Mechanical Engineering from PESCE, Mandya in the year 2010and M.Tech in CAMS from VVCE Mysore in the year 2013. He is life member of Indian Society of Technical Education (ISTE). His areas of interest include Biodiesel, Industrial Automation, 3D Printing, Artificial Intelligence and Machine Learning.

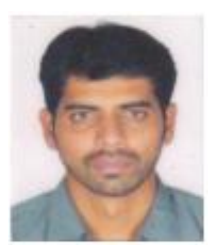

Dr. Vinay $\mathbf{K}$ B working as Associate professor at Mechanical Engineering Department, VVCE, Mysore. He completed B.E, M.Tech and Ph.D in Mechanical engineering from University of Mysore and Visvesvaraya Technological University. He has presented 16 papers in national and international conferences and published 07 papers in Journals. Teaching experience 15 years. Research interests are Incubation, Heat Transfer and fluid flow, Quality Management, Operations Management, Entrepreneurship, Engineering system Design. Life member of ISTE

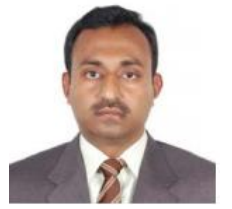

Dr G V Naveen Prakash received his BE degree in Mechanical Engineering from University of Mysore. M.Tech in Production Engineering Systems Technology from VTU and Ph.D in Mechanical Engineering from VTU in 2011. His major research interest areas are condition monitoring, composite and Biodiesel. He is working as Professor and Head in the Department of Mechanical Engineering, VVCE, Mysuru. He has more than 16 years of teaching, 10yeras of research and 1.5 years of industry experience. He is a life member of ISTE, SME and IE(I). 